Dayı, F. (2019). Net işletme sermayesinin likiditeye etkisi: BIST 30 şirketlerinde bir uygulama. KOCATEPEIIBBF Dergisi, Haziran 2019, 21(1), 47-58.

\title{
NET İŞLETME SERMAYESİNİN LİKİDİTEYE ETKİSİ: BIST 30 ŞİRKETLERİNDE BİR UYGULAMA
}

\section{FARUK DAYI 1}

ÖZ

İşletmeler günlük faaliyetlerini sürdürebilmek için yeterli düzeyde likiditeye sahip olmaları gerekmektedir. Bu nedenle işletme sermayesi ile likidite arasındaki ilişkinin incelenmesi gerekmektedir. Bu çalışmada net işletme sermayesi verimliliğinin likiditeye etkisi incelenmiştir. Uygulamada BIST 30 endeksindeki şirketlerin 2014-2018 dönemi finansal tablo verileri kullanılmıştır. Modelde net işletme sermayesi devir hızı, cari oran, asit test oranı, nakit oran, net işletme sermayesi, hasılat ve net işletme sermayesinin yönünü ifade eden değișken ile panel veri analizi yapılmıştır. Analiz sonuçlarında cari oran ve asit test oranı ile net işletme sermayesi devir hızı arasında anlamlı bir ilişki olmadığı görülmektedir. Net işletme sermayesi devir hızı, net işletme sermayesi ve net işletme sermayesin yönünü ifade eden değișken ile negatif yönde; nakit oran ve hasılat değișkenlerini pozitif yönde etkilediği tespit edilmiștir.

Anahtar Kelimeler: Net İşletme Sermayesi, Likidite, Borsa İstanbul

JEL Kodları: G24, G33, G10

\section{EFFECT OF NET WORKING CAPITAL ON LIQUIDITY: AN EXAMPLE IN BIST 30 COMPANIES}

\begin{abstract}
Companies are required to have sufficient liquidity to maintain their daily activities. Therefore, the relationship between working capital and liquidity needs to be examined. In this study, the effect of net working capital efficiency on liquidity is investigated. In the application, 2014-2018 period financial statements data of the companies in the BIST 30 index were used. In the model, a panel data analysis was performed with the variables that define the net working capital turnover ratio, current ratio, acid test ratio, cash ratio, net working capital, revenues and net working capital direction ( positively or negatively). There is no significant relationship between current ratio and acid test ratio and net working capital turnover ratio. Net working capital turnover rate, net working capital and net working capital are negatively in the direction of the variables expressing the direction; It has been determined that it affects the cash ratio and revenues variables positively.
\end{abstract}

Keywords: Net Working Capital, Liquidity, Istanbul Stock Exchange

JEL Codes: G24, G33, G10

${ }^{1}$ Dr. Öğretim Üyesi, Kastamonu Üniversitesi, İktisadi ve İdari Bilimler Fakültesi, İşletme Bölümü, fdayi@kastamonu.edu.tr - ORCID: 0000-0003-0903-1500 


\section{Gíkiș}

Şirketler varlıklarını etkin ve verimli kullandıkları sürece faaliyetlerini devam ettirebilirler. Kâr elde etmek bir amaç olmayıp varlıkların sürdürülebilirliği sağlandığı sürece şirketler hayatta kalabilmektedir. Bunun için varlıkların verimli kullanılması kadar, varlıkların niteliklerine uygun fonlarla finansmanı da gerekmektedir. Varlıklar, vade yapılarına göre dönen varlıklar ve duran varlıklar olmak üzere ikiye ayrılmaktadır. Cari aktif olarakta bilinen dönen varlıklar, şirketlerin günlük işlemlerinde kullanılmaktadır. Duran varlıklar ise uzun vadeli olduklarından şirketlerin yatırımları olarak aktifte yer almaktadır. Duran varlıklar işletmenin faaliyetini sürdürdüğü sürece var olduklarından sabit aktif olarak ifade edilmektedir. Şirketlerin kâr ve kârlılıklarını artırması, piyasa değerlerinin yükselmesi ve hedeflerine ulaşması için varlıkların verimli kullanılması gerekmektedir. $\mathrm{Bu}$ nedenle şirketlerin en iyi performansı alacakları projelere yatırım yapmaları önerilmektedir. Çünkü duran varlıklara yapılan yatırımın bazen geri dönüşü beklenenden çok uzun süreler alabilmektedir. Bu durumda yanlış yatırım kararları sonucunda atıl yatırım yapılmakta ve şirketler faaliyetlerini sürdürdükleri sürece ek maliyetlere katlanmak zorunda kalmaktadır. Şirketlerin faaliyetleri bu durumdan olumsuz etkilenerek, kârları azalmakta ve sektördeki rekabet düzeyleri düşmektedir. Çünkü işletme sermayesini oluşturan dönen varlıkların performansı, işletmenin günlük faaliyetini doğrudan etkilemektedir. Bu nedenle uzun vadeli yatırım kararlarının dışında dönen varlıkların da etkin ve verimli yönetilmesi şirketlerin hedeflerine ulaşması için oldukça önemlidir.

İşletme sermayesi, işletmelerin günlük işlemlerinin büyük bir kısmını oluşturmaktadır. Nakit varlıklar, ticari alacaklar, stoklar işletme sermayesinin büyük bir kısmını oluşturmaktadır. Şirketlerin günlük faaliyetlerinde çok sayıda nakit giriş ve çıkış işlemi gerçekleşmektedir (Ulusoy vd., 2019: 1983). Aldıkları ürünleri satarak nakde ve alacağa dönüştürmekte, hesaplar sürekli değișmektedir. Yeterli nakit varlıkların olmayışı borçların ödenmesini geciktirebilmekte hatta stoklar için yapılacak ödemelerde işletmelerin yasal ve finansal ciddi sorunlarla karşılaşmasına neden olabilmektedir. Örneğin stok almak isteyen bir işletme yeterli düzeyde nakdi yoksa karşılığında senet veya çek verebilir veya cari hesap usulü ile diğer bir ifadeyle veresiye borçlanabilir. Dolayısıyla dönen varlıklar ile kısa vadeli borçlar sürekli etkileşim içinde olup, cari oran net işletme sermayesinin değerlendirilmesinde sıkça kullanılmaktadır. Dönen varlıkların, kısa vadeli yabancı kaynaklara oranlanmasıyla hesaplanan cari oran, dönen varlıkların kısa vadeli yabancı kaynakları karşılama gücünü göstermektedir. Cari oranın yüksek olması işletmelerin net işletme sermayesinin olduğunu göstermektedir. Net işletme sermayesi finansal sürdürülebilirlik için şirketler için hayati öneme sahiptir. Net işletme sermayesi, uzun vadeli finansman kaynaklarıyla finanse edildiğinden, likidite ile ilişkinin incelenmesinin literatüre katkı sağlaması beklenmektedir. $\mathrm{Bu}$ amaçla net işletme sermayesi verimliliğinin likiditeye etkisi incelenmektedir.

\section{LİTERATÜR}

Yatırım yapıldıktan sonra faaliyetlerin sürdürülebilmesi için işletmelerin ihtiyaç duydukları sermayeye işletme sermayesi denilmektedir (Aksoy ve Yalçıner, 2008: 5). İşletmeler sermaye bütçelemesi için uzun vadeli finansman kaynakları kullanmakta; özellikle ilk kurulduklarında, varlıklar özkaynaklar ile finanse edilmektedir (Mueller, 1953: 157-161). Duran varlık yatırımı yapıldıktan sonra faaliyetlerin başlaması ve gelir elde edilmesine kadar geçen sürede işletme sermayesi ihtiyacı doğmaktadır. İşletme sermayesi yönetimi, nakit varlıklar, menkul kıymetler, alacaklar, stoklar ve diğer dönen varlıklardan oluştuğu gibi işletmenin kısa vadeli borçlarını da kapsamaktadır (Aksoy ve Yalçıner, 2008: 6). İşletme sermayesi unsurları, günlük işlemlerde birçok kararın alınmasını gerektirmektedir. Örneğin, işletmeler stoklara yatırım yapmak istediklerinde ne kadar stok bulunduracaklarına, stokları vadeli mi yoksa peşin mi satın alacaklarına işletme sermayesi yönetimiyle karar vermektedir.

İşletme sermayesi ile üretim veya hizmet kapasitesi arasında yakın bir ilişki vardır (Sagan, 1955: 121-122). Tam kapasite çalışabilmek için gerekli stokların temin edilmesi, satılan ürünlerin karşılığında alacakların tahsili ve bunların tekrar üretime dahil edilmesi için işletme sermayesi unsurlarının yönetiminde optimum kararların alınması gerekmektedir. Şirketler yatırım kararı aldıkların da işletme sermayesine ihtiyaç duymaktadırlar. İşlet yolunda gitmediğinde, finansal bir kriz çıktığında, işletmelerin olumsuz bir durum ile karşılaşmaması için yeterli düzeyde işletme sermayesi bulundurmalıdır. Bu durumda işletme sermayesi ihtiyacının ne kadar olduğunun tespit edilmesi gerekmektedir. Ayrıca işletme sermayesi ihtiyacı üretim, hizmet ve ticari işletmelerin büyüklüklerine göre değişmektedir. Üretim işletmelerinin varlıklarının büyük bir kısmı duran varlıklardan oluşmaktayken, ticari ve hizmet işletmelerinde ise dönen varlıkların daha fazla olduğu görülmektedir. Bu nedenle şirketler, faaliyet gösterdikleri sektörün ortalama net işletme sermayesi tutar kadar işletme sermayesi bulundurmaları tavsiye edilmektedir.

Net işletme sermayesi, dönen varlıkların kısa vadeli yabancı kaynakları karşılamasından sonra kalan tutar olarak ifade edilebilir. Bu durumda işletmelerin kısa vadeli yabancı kaynaklarından daha yüksek tutarlarda dönen varlıklarının olması gerekir. Dönen varlıklar ile kısa vadeli yabancı kaynaklar birbirlerine eşit olması durumunda işletmenin net işletme sermayesi sıfırdır. Bu durumda sadece kısa vadeli yabancı kaynakları

KOCATEPEIİBF Dergisi - Cilt: 21, Sayı: 1, Yll: Haziran 2019, Sayfalar: 47-58.

KOCATEPEIIBF Journal - Volume: 21, Issue: 1, Year: June 2019, Pages: 47-58. 
ödeyecek kadar işletme sermayesinin olduğu görülmektedir. Kısa vadeli yabancı kaynakların, dönen varlıklardan fazla olması durumunda ise net işletme sermayesi negatif değer almaktadır. Bu durum kısa vadeli yabancı kaynakların dönen varlıklardan daha fazla olduğunu göstermektedir. Şirketlerin kısa vadeli yabancı kaynaklarıyla duran varlıklarını finanse etmesi, varlık ve kaynaklardaki vade uyumunu bozmaktadır. Böylece finansman kaynaklarında vade uyumsuzluğu vadesi gelen borçların ödenme olasılığını azaltmaktadır. Böyle bir durumda işletmenin finansal risk düzeyi yükselmektedir. Finansal risk düzeyini düşürmek için varlıklar ile kaynakların birbirleriyle uyumlu yönetilmesi gerekmektedir.

Net işletme sermayesi, dönen varlıkların kısa vadeli yabancı kaynaklardan kalan kısmı olduğuna göre dönen varlıkların bilançodaki yerine net işletme sermayesi yazılması mümkündür. Kısa vadeli yabancı kaynaklar dönen varlıklardan düşüldüğünden bilançoda borç olarak sadece uzun vadeli yabancı kaynaklar yer almaktadır. Bu durumda işletmenin net işletme sermayesi, duran varlıklar gibi uzun vadeli olduklarından uzun vadeli finansman kaynaklarıyla finanse edilmektedir. Net işletme sermayesi, işletmenin likiditesini artırmakta ve uzun vadeli finansman kaynaklarıyla finanse edildiğinden kısa vadeli borçların ödenmesinde sorun olmayacağı düşünülmektedir. Çünkü vade uzun olduğundan, işletmenin ihtiyaç duyduğu günlük kısa vadeli yabancı kaynakları ödemede sorun yaşama olasıllğı düşmektedir. Net işletme sermayesi varlıklar ve kaynaklar arasındaki dengenin sağlanmasında önemli bir işlev görmektedir.

\section{LITERATÜR TARAMASI}

İşletme veya çalışma sermayesi ile ilgili literatürde yapılmış çok sayıda çalışma vardır. İşletme sermayesi unsurları, işletme sermayesi finanslama politikaları, işletme sermayesi ile performans arasındaki ilişki, makroekonomik değişkenlerin işletme sermayesi üzerine etkisi gibi çeşitli konularda birçok çalışma yapılmıştır. Özellikle de işletme sermayesi ile kârlılık arasındaki ilişkiyi inceleyen çalışmalar oldukça fazladır. Ancak net işletme sermayesi ile likidite arasındaki ilişkiyi inceleyen çalışmaya literatürde pek rastlanılmamıştır. Bu nedenle bu kısımda genel olarak işletme sermayesi ile ilgili yapılmış çalışmalara kısaca yer verilmiştir.

İşletme sermayesi ile kârlılık arasındaki ilişkiyi ölçen bir çalışmada Keskin ve Gökalp (2016), finans yöneticilerinin işletme sermayesini etkin yönettikleri takdirde firmanın kârıllığını artırabileceklerini ifade etmiştir. Aytürk ve Yanık (2015) KOBİ'lerin çalışma sermayesi ile kârlılıkları arasındaki ilişkiyi inceledikleri çalışmada etkin çalışma sermayesi yönetiminin kârlılığı artırdığını ifade etmiștir. Aydoğuş ve Vurur (2017) net kâr marjının, aktif kârlılık oranı ve cari oran ile pozitif yönlü; kısa vadeli borçların devir hızı ile negatif yönlü bir ilişki olduğunu tespit etmiştir. Öz ve Güngör (2007) satışlardaki büyüme ve mali duran varlıklar ile kârlılık arasında pozitif yönlü ve anlamlı; işletme sermayesini temsil eden değişkenler ile kârlılık arasında negatif yönde bir iliş̧kinin olduğunu ifade etmiștir. Benzer bir çalışmada da Coşkun ve Kök (2011) işletme sermayesinin nakit dönüş süresi, alacakların tahsil süresi ve stok devir süresi ile negatif yönlü bir ilişkinin olduğu tespit etmiş̦tir. Dursun ve Ayrıçay (2012) işletme sermayesi unsurları ile brüt kârlılık oranı arasında negatif yönlü bir ilişki olduğunu tespit etmiştir. Garcia-Teruel ve Martinez-Solano (2009) şirketlerin nakit dönüş süresini kısaltmalarının kârlılıklarını olumlu yönde etkilediğini ifade etmektedir. Atmaca (2016) finansal oranlar ile sermaye bileșenlerinin kârlılığa etkisini inceledikleri çalışmada anlamlı bir ilişkinin olmadığı tespit edilmiștir. Karaduman vd. (2010) işletme sermayesi unsurlarının kârlılığı etkilediğini ifade etmiştir. Akbulut (2011) işletme sermayesi ile kârlllık arasında negatif yönlü bir ilişski bulmuştur. Çakır ve Küçükkaplan (2012) işletme sermayesi unsurlarının kârlılık ve firma değeri üzerine etkisini ölçtükleri çalışmada cari oran ile kaldıraç oranının aktif kârlılık oranıyla negatif yönde; asit test oranı, stok devir hızı ve aktif devir hızının ise kârlıı̆̆̆ pozitif yönde etkilediği tespit edilmiştir. Raheman ve Nasr (2007) Pakistanlı şirketlerin işletme sermayesi yönetimin kârlılık üzerine etkisini inceledikleri çalışmada, işletme sermayesi ile kârlılık arasında güçlü bir ilişkinin olduğu tespit edilmiştir. Uremadu vd. (2012) Nijeryalı şirketlerin işletme sermayesi, likiditeleri ve kârlılıklarını inceledikleri çalışmada borç devir hızı, stok devir süresi ile nakit dönüşüm süresinin kârlılığı etkilediğini ifade etmiştir. Akoto vd. (2013) alacak devir süresi ile kârlılık oranları arasında negatif yönde; nakit dönüşüm süresi, cari oran, işletmenin büyüklügü ve dönen varlık devir hızı ile kârlılık arasında pozitif yönlü bir ilişki tespit etmiştir. Iqbal ve Zhuquan (2015) işletme sermayesi unsurları ile aktif kârlılık ve özsermaye kârlılık oranları arasında negatif yönlü bir iliş̧ki olduğunu ifade etmiștir. Makori ve Jagongo (2013) alacakların tahsil gücü ile kârlılık arasında ve stok devir süresi ve borç ödeme süresi ile kârlılık arasında negatif yönlü ilişki olduğunu tespit etmiştir.

Gill vd. (2010) brüt satış kârlılığı ve nakit dönüşüm süresi arasında anlamlı bir ilişki olduğunu belirtmiştir. Pouraghajan ve Emamgholipourarchi (2012) işletme sermayesi yönetiminin kârlılı ve firma değeri üzerindeki etkisini ölçtükleri çalışmada, işletme sermayesi yönetimi ile kârlılık arasında pozitif yönlü bir ilişki olduğunu, piyasa değeri ile herhangi bir ilişki olmadığı ifade etmiştir. Saglam vd. (2016) çalışma sermayesi ile kârlılık arasındaki ilişkiyi inceledikleri çalışmada, brüt kâr ile alacaklar ve stok devir süresi arasında anlamlı bir ilişki olduğunu ancak firmanın kârını önemli bir düzeyde etkilemediklerini ifade etmiştir. İ̧̧letme sermayesi ile kârlılığın arasındaki ilişkinin incelendiği başka bir çalışmada, büyük ve küçük

KOCATEPEIİBF Dergisi - Cilt: 21, Sayı: 1, Yll: Haziran 2019, Sayfalar: 47-58.

KOCATEPEIIBF Journal - Volume: 21, Issue: 1, Year: June 2019, Pages: 47-58. 
ve orta ölçekli şirketlerde farklılıklarını inceleyen Karadağlı (2012), büyük şirketlerden küçük ve orta ölçekli şirketlere doğru hem operasyon gelirleri hem de piyasa getirisi bakımından farklılıklar olduğunu tespit etmiştir. Ticari alacakların tahsilinin, nakit dönüş süresinden daha anlamlı olduğu ifade edilmiştir.

Dash ve Hanuman (2009), net çalışma sermayesi ile likidite ve kârlılık arasındaki ilişkiyi incelemiștir. Kârlılığı artıracak, stokların sınırlandırıldığı bir işletme sermayesi yönetimi tavsiye edilmektedir. Lazaridis ve Tryfonidis (2006) nakit döngüsü ve kârlılık arasında anlamlı bir ilişki bulmuştur. Ebenezer ve Asiedu (2013) nakit oran, alacakların tahsil süresi ve stok devir süresinin, işletmelerin kârlılıklarını etkilediğini tespit etmiştir. Dong ve Su (2010) kârlılık ile nakit dönüșüm süresi arasında kuvvetli negatif yönlü bir ilişki olduğunu tespit etmiştir. Falope ve Ajilore (2009) nakit dönüşüm süresi, alacakların tahsil süresi, stok devir süresi ve borç ödeme süresi ile kârlılık arasında önemli derecede negatif yönlü bir ilişki olduğunu belirtmiştir.

İșletme sermayesi finanslama stratejileriyle ilgili bir çalışmada Şekeroğlu (2013) işletme sermayesi finanslama stratejileriyle firmaların çeşitli kârlılık oranları arasında ilişki olduğu tespit edilmiştir. Kök vd. (2013) çalışma sermayesi politikalarının sektörlere göre farklılık gösterme durumunu inceledikleri çalışmada, sektörel veya makroekonomik dalgalanmaların nakit dönüş sürelerinde etkisinin geçici olduğunu, çalışma sermayesi tutarının belirli bir ortalama etrafında döndüğü ifade edilmiştir. İșletme sermayesi ile sabit aktif arasındaki ilişkiyi ölçen bir çalışmada Çelik ve Boyacıoğlu (2013), şirketlerin duran varlık yatırımlarının işletme sermayesine önemli bir etkisi olduğu belirtilmiştir. Şahin (2011) işletme sermayesi politikaları ile finanslama stratejileri arasındaki ilişkiyi incelediği çalışmada şirketlerin muhafazakâr bir çalışma sermayesi politikasının belirlemesinin daha faydalı olacağı ifade edilmiștir. Poyraz (2012) işletme sermayesi finanslama stratejisini bankacılık sektöründe uyguladığı çalışmada cari oran ile kârlılık oranları arasında ters yönlü bir ilişki olduğunu tespit etmiștir.

İşletme sermayesi gereksinimlerini inceleyen bir çalışmada Doğan ve Elitaş (2014) işletme sermayesi unsurları ile aktif kârılık oranı, nakit akışı, nakit döngüsü arasında pozitif yönlü ve işletme sermayesi ile kaldıraç oranı ve firma büyüklüğü arasında ise negatif yönlü ilişkinin olduğu tespit edilmiștir. Aksoy (2013) işletme sermayesi ihtiyacının Prais-Winsten modeli ile tespit ettiği çalışmada nakit dönüşüm süresi ile firmanın büyüklüğü ve teknik likidite arasında pozitif yönlü; özsermaye getiri oranı ile anlamlı bir ilişki olmadığını tespit etmiştir. İltaş (2016) TCMB sektör bilançolarından yararlanarak işletme sermayesi ihtiyacını etkileyen faktörler üzerinde inceleme yapmıștır. İșletme sermayesi ihtiyacının, uzun dönemde nakit dönüşüm süresi ve aktif kârlılık oranı ile negatif yönde; kaldıraç oranı ve cari oran arasında ise pozitif yönde bir ilişkinin olduğu tespit edilmiştir. Appuhami (2008) işletme sermayesi ihtiyacının, sermaye harcamalarından önemli derecede etkilendiğini tespit etmiştir. Apak vd. (2016) işletmelerin kısa ve uzun vadeli banka kredilerinin işletme sermayesi, nakit döngüsü ve kısa vadeli yabancı kaynaklar üzerindeki etkisinin incelemiştir. Nakit varlıkların ve net çalışma sermayesinin uzun vadede banka kredisi tutarını etkilediği tespit edilmiştir.

Kendirli ve Konak (2014) işletme sermayesinin performansını değerlendirdikleri çalışmada net nakit dönüş süresi, alacak devir hızı ve aktif kârlılık oranının özsermaye kârlılık oranı ile \%10 anlamlılık düzeyinde negatif yönlü bir ilişki olduğunu tespit etmiştir. İşletme sermayesinin şirketlerin performansı üzerine etkisinin incelendiği başka bir çalışmada Yamaltdinova (2018), stokların etkin yönetilmesinin firmanın performansını olumlu yönde etkilediğini ifade etmiştir. Firma performansının işletme sermayesinin üzerindeki etkisini ölçen bir çalışmada Aygün (2012) aktif kârlılık oranı ile alacakların ortalama tahsil süresi, stok devir süresi ve borçların ödenme süresi arasında ters yönde negatif bir ilişki olduğunu ifade etmiştir. Demireli vd. (2014) işletme sermayesi ile şirketin performansı arasındaki ilişkiyi inceledikleri çalışmada, cari oran, kaldıraç oranı, dönen varılıların toplam aktife oranı ile özsermaye kârlılık ve aktif kârllık oranları arasında anlamlı bir iliş̧ki olduğunu tespit etmiştir. Mehrotra (2013) finansal tablo verilerinden yararlanarak oran analizi yöntemi ile çeşitli şirketlerin işletme sermayelerinin etkinliğini incelemiştir.

İşletme sermayesi unsurlarıyla makroekonomik göstergeler arasında ilişkinin incelediği bir çalışmada Akel ve İltaş (2016) makroekonomik göstergelerin işletme sermayesi üzerinde etkili olduğunu tespit etmiștir. Çelik vd. (2016) net çalışma sermayesi ile makroekonomik göstergeler arasındaki ilişkiyi incelemiştir. Net çalışma sermayesinin, faiz oranı, döviz kuru ve enflasyondan etkilendiği ifade edilmiştir. Mousavi ve Jari (2012) işletme sermayesi yönetimi ile şirketin finansal performansı arasında pozitif yönlü bir ilişki olduğunu tespit etmiştir.

\section{MATERYAL VE YÖNTEM}

Uygulama Borsa İstanbul BIST 30 endeksinde işlem gören şirketler üzerinde yapılmıştır. BIST 30 endeksi borsa değeri ve işlem hacmi en yüksek șirketlerden oluşmaktadır. 2018 yılında BIST 30 endeksinde yer alan şirketler analize dâhil edilmiştir. BIST 30 endeksinde 2017 ve önceki yıllarda görülen değissimler dikkate 
alınmamıştır. Çalışmanın ana kütlesi 2018 yılı itibariyle BIST 30 endeksinde yer alan 30 şirketten oluşmaktadır. Ancak 7 şirket ( 6 banak ve 1 yatırım ortaklı̆̆ı şirketi) finans sektöründe faaliyet gösterdiklerinden uygulamaya dâhil edilmemiştir. Örneklemdeki şirketlerin listesi Tablo 1'de verilmiştir.

Tablo 1: Örneklemdeki Şirketlerin Listesi

\begin{tabular}{|c|c|}
\hline No & Şirketlerin Ad ve Ticaret Ünvanları \\
\hline 1 & Arçelik A. Ș. \\
\hline 2 & Aselsan Elektronik Sanayi ve Ticaret A. Ş. \\
\hline 3 & BİM Birleșik Mağazalar A. Ș. \\
\hline 4 & Doğan Şirketler Grubu Holding A. Ş. \\
\hline 5 & ENERJISA Enerji A. Ș. \\
\hline 6 & Ereğli Demir ve Çelik Fabrikaları T. A. Ș. \\
\hline 7 & Ford Otomotiv Sanayi A. Ş. \\
\hline 8 & Hacı Ömer Sabancı Holding A. Ș. \\
\hline 9 & Kardemir Karabük Demir Çelik Sanayi ve Ticaret A. Ș. \\
\hline 10 & Koç Holding A. Ş. \\
\hline 11 & Koza Altın İșletmeleri A. Ș. \\
\hline 12 & Koza Anadolu Metal Madencilik İșletmeleri A. Ş. \\
\hline 13 & Pegasus Hava Tașımacılığı A. Ș. \\
\hline 14 & PETKIM Petrokimya Holding A. Ș. \\
\hline 15 & Soda Sanayi A. Ş. \\
\hline 16 & Tav Havalimanları Holding A. S.. \\
\hline 17 & Tekfen Holding A.Ș. \\
\hline 18 & TOFAȘ Türk Otomobil Fabrikası A.Ş. \\
\hline 19 & Türkcell İletișim Hizmetleri A. Ş. \\
\hline 20 & Türkiye Petrol Rafineleri A. Ş. \\
\hline 21 & Türk Hava Yolları A. Ș. \\
\hline 22 & Türk Telekomünikasyon A. Ș. \\
\hline 23 & Türkiye Şișe ve Cam Fabrikaları A. Ş. \\
\hline
\end{tabular}

Uygulamada veri setinin tespitinde bir sınırın belirlenmesi gerekmektedir. 2018 yılı baz alındığından, 2018 yılında BIST 30 endeksinde yer alan șirketlerin son beş yıllık verileri çalıșmada kullanılmıștır. 2018 yılından önce endeksteki değișiklikler dikkate alınmamıștır. Çünkü her yıl endeks güncellendiğinden șirketlerin verileri farklılık gösterebilmektedir. Bu durumda son beş yılda endeks kapsamında süreklilik arz eden şirketlerin analize dâhil edilmesi örneklemdeki şirket sayısını olumsuz yönde etkileyeceğinden, 2018 yılında endekste yer alan şirketlerin geçmiş 5 yıllık verileri çalışma kullanılmıştır. Çalışmada kullanılan değișkenler Tablo 2'de verilmiștir.

Tablo 2: Değișkenlerin Listesi

\begin{tabular}{|l|c|c|c|c|}
\hline Değișkenler & Kısaltma & Nitelik & Frekans & Kaynak \\
\hline Net İșletme Sermayesi Devir Hızı & nisdh & Bağımlı & Yıllık & Finansal Tablolar \\
\hline Cari Oran & cari & Bağımsız & Yıllık & Finansal Tablolar \\
\hline Asit Test Oranı & asit & Bağımsız & Yıllık & Finansal Tablolar \\
\hline Nakit Oran & nakit & Bağımsız & Yıllık & Finansal Tablolar \\
\hline Net İșletme Sermayesi & nișl & Bağımsız & Yıllık & Finansal Tablolar \\
\hline Hasılat & hasılat & Bağımsız & Yıllık & Finansal Tablolar \\
\hline Net İșletme Sermayesinin İșareti & nis & Bağımsız & Yıllık & Finansal Tablolar \\
\hline
\end{tabular}

Modelde yer alan değişkenlerin frekans düzeyleri yıllıktır. Veriler, şirketlerin bağımsız denetimden geçmiş yıllık konsolide finansal tablolarından elde edilmiştir. Bazı değişkenler ise finansal tablo verilerinden yararlanarak hesaplanmıştır. Literatürde işletme veya çalışma sermayesinin kârlılık ve finanslama stratejisi üzerine etkisi ile ilgili birçok çalışma yapılmıştır. Bu çalışmada onlardan farklı olarak net işletme sermayesi kullanılmıştır. Net işletme sermayesi örneklemdeki şirketlerde oldukça farklılık göstermektedir. Bu nedenle net işletme sermayesinin logaritması alınmıştır. Net işletme sermayesinin devir hızının likidite üzerine etkisini değerlendirmek için bağımsız değişkenlerde likidite oranları kullanılmıştır. Ayrıca net işletme sermayesinin negatif veya pozitif olmasının likidite üzerine etkisini test etmek için " 0 " veya "1" değerlerinden oluşan bir bağımsız değişken kullanılmıştır. Satışlar ile likidite düzeyi arasında ilişkinin yüksek olması beklendiğinden modelde ayrıca hasılat değişkeni de ilave edilmiştir. Hasılat değişkeninin de logaritması alınmıştır. Net işletme sermayesi devir hızı ise hasılatın, net işletme sermayesine bölünmesiyle hesaplamıştır. Böylece oranın daha anlamlı değerler alacağı düşünülmektedir. Çalışmanın modeli aşağıda verilmiştir:

$$
Y_{\text {nisdh }}=\beta_{1} X_{\text {cari }}+\beta_{2} X_{\text {asit }}+\beta_{3} X_{\text {nakit }}+\beta_{4} X_{\text {nisl }}+\beta_{5} X_{\text {hasilat }}+\beta_{6} X_{\text {nis }}+u
$$


23 şirketin 5 yıllık verileri kullanılacağından, uygulamada zaman serisi analizinin yapılması mümkün değildir. Bu nedenle yatay ve dikey kesitin bir arada kullanıldığı panel veri analiz yönteminin kullanılması gerekmektedir. Panel veri analizinde en küçük kareler yönteminin sıkça kullanıldığı görülmektedir. Uygulamada ver setindeki zaman serisinin az olmasından dolayı değişkenler arasında birim kök testi yapılamamıştır. Çünkü STATA 15 paket programı birim kök testinde, yeterli düzeyde veri olmadığından hata vermiştir. Panel veride, Rassal Etkiler veya Sabit Etkiler yöntemlerinden hangisi ile analizin yapılacağına Hausman testi yapılarak karar verilmektedir. Hausman testi sonucuna göre STATA 15 paket programı kullanılarak Panel veri analizi yapılmıștır.

\section{BULGULAR}

Bu kısımda ilk olarak değişkenlerin tanımlayıcı istatistiki sonuçlarına yer verilmiștir. Ardından modeldeki değişkenlerin korelasyon ilișkisi test edilmiștir. Panel veri analizinde hangi yöntemin kullanılacağına karar vermek için Hausman Testi yapılmıştır. Son kısımda ise analiz sonuçlarına yer verilmiştir.

\subsection{Tanımlayıcı İstatistikler}

Modelin tanımlayıcı istatistik sonuçları Tablo 3'de verilmiştir. Bazı şirketlerin çalışma yapıldığı esnada 2018 yılı finansal tablolarına ulaşılamadığından (yayın aşamasında olduklarından) 2018 yılı verileri analize dâhil edilmemiștir. Bu nedenle 115 gözlem değeri yerine 109 gözlem değeri ile analiz yapılmıștır.

Tablo 3: Tanımlayıcı İstatistik Sonuçları

\begin{tabular}{|l|c|c|c|c|c|}
\hline Değișkenler & Gözlem Sayısı & Ortalama & Standart Sapma & Minimum & Maksimum \\
\hline nisdh & 109 & 1,1264 & 0,1385 & 0,8579 & 1,7116 \\
\hline cari & 109 & 2,2073 & 2,7361 & 0,18 & 17,4 \\
\hline asit & 109 & 1,8551 & 2,4369 & 0,17 & 14,78 \\
\hline nakit & 109 & 1,2253 & 2,4156 & 0,02 & 14,34 \\
\hline netisl & 109 & 6,5467 & 1,0601 & 4,1342 & 9,2698 \\
\hline hasılat & 109 & 7,2931 & 0,9877 & 5,9201 & 9,9189 \\
\hline nis & 109 & 0,7431 & 0,4389 & 0 & 1 \\
\hline
\end{tabular}

Tanımlayıcı istatistik sonuçları incelendiğinde net ișletme sermayesi devir hızının 0,85 ile 1,71 arasında değiştiği görülmektedir. Net işletme sermayesi ve hasılat değişkenlerinin logaritması alındığından, net işletme sermayesi devir hızı yüksek çıkmamıştır. Cari oran 0,18 ile 17,4 arasında değiş̧im gösterdiği görülmektedir. Asit test oranı 0,17 ile 14,78 arasında ve nakit oran ise 0,02 ile 14,34 arasında değer almaktadır. Değişim aralığının yüksek olmasından dolayı şirketlerin likidite yapılarında önemli farklılıklar olabileceği düşünülmektedir. Net işletme sermayesinin negatif veya pozitifliği ifade eden nis değişkeninin ortalaması \%74'dür. Dolayısıyla şirketlerin \%26'lık kısmının net işletme sermayesi negatiftir. Net işletme sermayesinin negatif olması pek beklenen bir durum değildir. Söz konusu şirketlerin finansal yapılarında bir problem olduğunu düşündürmektedir. Çünkü net işletme sermayesinin negatif olması kısa vadeli borçlarla duran varlıkların finanse edildiğini göstermektedir.

\subsection{Korelasyon Testi Sonuçları}

Modeldeki değișkenler arasında korelasyon olup olmadığını tespiti için korelasyon testi yapılmıştır. Korelasyon testinin yüksek olması modelde oto korelasyona neden olabilmektedir. Korelasyon testi sonuçları Tablo 4'de verilmiştir.

Tablo 4: Korelasyon Testi Sonuçları

\begin{tabular}{|l|c|c|c|c|c|c|c|}
\hline & nisdh & cari & asit & nakit & netis & hasılat & nis \\
\hline nisdh & 1 & & & & & & \\
\hline cari & $-0,3799$ & 1 & & & & & \\
\hline asit & $-0,3793$ & 0,9948 & 1 & & & & \\
\hline nakit & $-0,3441$ & 0,9836 & 0,9874 & 1 & & & \\
\hline netis & $-0,5608$ & $-0,0805$ & $-0,0834$ & $-0,0816$ & 1 & & \\
\hline hasilat & 0,1486 & $-0,3888$ & $-0,3934$ & $-0,3679$ & 0,7229 & 1 & \\
\hline nis & $-0,2846$ & 0,3181 & 0,2992 & 0,2516 & 0,1628 & 0,0241 & 1 \\
\hline
\end{tabular}

Korelasyon testi sonuçları incelendiğinde modeldeki bağımlı değişken ile bağımsız değişkenler arasında korelasyon ilişkisinin yüksek olmadığı görülmektedir. En düşük ilgileşim, net işletme sermayesi devir hızı 
(nisdh) ile hasılat arasında olduğu görülmektedir. En yüksek korelasyon katsayısı net işletme sermayesi devir hızı ile net işletme sermayesi arasında negatif yönde $\% 56$ oranındadır. Net işletme sermayesinin yönü ile net işletme sermayesi arasında ise pozitif yönde \%16 oranında korelasyon vardır.

\subsection{Hausman Testi Sonucu}

Panel veri analizinde Rassal Etkiler veya Sabit Etkiler yöntemlerinden hangisiyle analizin yapılacağına karar vermek için Hausman Testi yapılmaktadır. Hausman Testi sonuçları Tablo 5'de verilmiştir.

Tablo 5: Hausman Testi Sonuçları

\begin{tabular}{|l|c|c|c|c|}
\hline & \multicolumn{2}{|c|}{ Katsayılar } & (b-B) & sqrt (diag(V_b-V_B)) \\
\hline & fe (b) & re (B) & Fark & S.E. \\
\hline Cari & 0,0040 & 0,0013 & 0,0029 & 0,0082 \\
\hline Asit & 0,0090 & 0,0025 & 0,0064 & 0,0099 \\
\hline Nakit & $-0,0124$ & $-0,0040$ & $-0,0083$ &. \\
\hline netisl & $-0,2158$ & $-0,1933$ & $-0,0225$ & 0,0035 \\
\hline hasılat & 0,1725 & 0,1699 & 0,0025 & 0,0126 \\
\hline nis & $-0,0207$ & $-0,0270$ & 0,0062 & 0,0026 \\
\hline \multicolumn{2}{l}{ Prob>chi2 $\mathbf{0 , 0 0 0 0}$} \\
\hline
\end{tabular}

Hausman testi sonuçları incelendiğinde Prob değerinin 0,005'den küçük olması sabit etkiler yöntemiyle analizin yapılması gerektiğini göstermektedir.

\subsection{Panel Veri Analiz Sonucu}

Calıșmada BIST 30 endeksinde yer alan 23 șirketin 2014-2018 dönemi verilerinden olușan bir model geliştirilmiş̧ir. Bazı şirketlerin 2018 yılı verisi eksik olduğundan 109 veri setinden oluşan bir model ile panel veri analizi yapılmıştır. Analiz sonuçları Tablo 6'da verilmiştir.

Tablo 6: Panel Veri Sabit Etkiler Modeli Sonuçları

\begin{tabular}{|c|c|c|c|c|}
\hline$R^{2}:$ & 0,9532 & & & \\
\hline Gözlem Sayısı: & 109 & $f(6,8$ & 271,39 & \\
\hline Şirket Sayısı: & 23 & Prob & 0,0000 & \\
\hline nisdh & Katsayı & Standart Hata & $t$ & $P>t$ \\
\hline cari & 0,0043 & 0,0142 & 0,30 & 0,764 \\
\hline asit & 0,0090 & 0,0169 & 0,53 & 0,595 \\
\hline nakit & 0,0124 & 0,0059 & $-2,10$ & 0,039 \\
\hline netișl & $-0,2158$ & 0,0059 & $-36,08$ & 0,000 \\
\hline hasılat & 0,1725 & 0,0140 & 12,30 & 0,000 \\
\hline nis & $-0,0207$ & 0,0078 & $-2,66$ & 0,009 \\
\hline $\mathrm{C}$ & 1,2855 & 0,0932 & 13,79 & 0,000 \\
\hline sigma_u & 0,039 & & & \\
\hline sigma_e & 0,016 & & & \\
\hline rho & 0,850 & & & \\
\hline
\end{tabular}

Modelin açıklama gücünü gösteren $R^{2}$ değeri \%95 olup modelin açlklama gücünün yüksek olduğunu göstermektedir. Cari oran ve asit test oranı modelde anlamsız çıkmıștır. Aydoğmuş ve Vurur (2017), Çakır ve Küçükkaplan (2012), Akoto vd. (2013), Poyraz (2012), İltaș (2016) ve Demireli vd. (2014), cari oranın modellerinde pozitif veya negatif yönde anlamlı çıktığını ifade etmişlerdir. Oysaki çalışmada cari oran anlamsız çıkmıştır. Çakır ve Küçükkaplan (2012) tarafından yapılan çalışmada asit test oranının işletmenin kârlılığını olumlu yönde etkilediği tespit edilmiștir. Analiz sonucunda asit test oranı anlamsız çıkmıștır. Ebenezur ve Asiedu (2013) nakit oranın işletmelerin kârllıklarını pozitif yönde etkilediklerini ifade etmiş̦tir. Çalışmada nakit oran ile net çalışma sermayesi devir hızı arasında negatif yönlü \%1 ilişsi tespit edilmiştir. Nakit oran \%1 arttığında, net işletme sermayesi devir hızı \%1 oranında artmaktadır. Nakit varlıklardaki artışın, net işletme sermayesini artırması beklenmektedir. Nakit varlıklar, kısa vadeli yabancı kaynaklarıyla dışında herhangi bir kaynak veya varlık ile artırıldığında net işletme sermayesi devir hızı artmaktadır. Net işletme sermayesi devir hızı ile net işletme sermayesi arasında $\% 21$ oranında negatif yönlü bir ilişki vardır. Net işletme sermayesinin artması devir hızını düşürmektedir. Çünkü net işletme sermayesi, satışlardaki artıştan daha yüksek oranda artmış olabilir. Bu durumda şirketin net işletme sermayesi satışlardan daha fazla arttığından oran düşmektedir. Net işletme sermayesi ile hasılat arasında pozitif yönde \%17 oranında bir ilişsi olduğu tespit edilmiştir. Satışlar \%1 arttıkça net işletme sermayesi devir hızı \%17 oranında artmaktadır. Net işletme sermayesinin negatif veya pozitif olmasının net işletme sermayesi devir hızı ile aralarında bir ilişki olup olmadığını incelemek için nis değişkeni modele dâhil edilmiştir. Net işletme sermayesi devir hızı ile nis değişkeni arasında \%2 negatif yönlü ilişski olduğu tespit edilmiştir. Net işletme 
sermayesi negatif veya pozitif olduğunda net işletme sermayesi devir hızı artmakta veya azalmaktadır. Bu durumda net işletme sermayesi devir hızı, net işletme sermayesinin negatif olmasından pozitif yönde etkilenmektedir. Örneğin net işletme sermayesinin negatif olduğu şirketler incelendiğinde, şirketlerin kısa vadeli yabancı kaynaklarıyla dönen varlıklarından çok fazla olduğu görülmektedir. Bu durumda net işletme sermayesinin negatif olması, net işletme sermayesi devir hızının yüksek hesaplanmasına neden olabilmektedir. Dönen varlıklar ile kısa vadeli yabancı kaynaklar arasındaki aralık azaldığında net işletme sermayesinin tutarı düşmektedir.

\section{SONUÇ}

Net işletme sermayesi şirketlerin günlük hayatlarında en çok kullandıkları varlılar olup işletmenin likidite düzeyini doğrudan etkilemektedir. Net işletme sermayesi, uzun vadeli finansman kaynaklarıyla finanse edilmektedir. Bu nedenle net işletme sermayesinin verimli kullanılması gerekmektedir. Ayrıca net işletme sermayesi likidite ile yakından ilişkilidir. Net işletme sermayesinin likidite düzeyi yüksek varlıklardan oluşması işletmelerin likiditesini güçlendirmektedir. Bu çalışmada şirketlerin günlük işlerinde sürekli kullandıkları işletme sermayesi ile likidite arasındaki ilişki incelenmiştir.

Aydoğmuş ve Vurur (2017), Çakır ve Küçükkaplan (2012), Akoto vd. (2013), Poyraz (2012), iltaş (2016) ve Demireli vd. (2014), cari oran ile şirketlerin kârlılı̆̆ arasında anlamlı bir ilişki bulmuştur. Çalışmanın sonucunda ise cari oran modelde anlamsız çıkmışır. Çakır ve Küçükkaplan (2012) tarafından yapılan çalışmada asit test oranının işletmenin kârlılığını olumlu yönde etkilediği tespit edilmiştir. Ancak çalışmada asit test oranı anlamsız çıkmıştır. Ebenezur ve Asiedu (2013) nakit oranın işletmelerin kârlılıklarını pozitif yönde etkilediklerini ifade etmiştir. Analiz sonucu literatüre benzer bir şekilde nakit oran ile net çalışma sermayesi devir hızı arasında negatif yönde \%1'lik bir ilişki tespit edilmiştir. Net işletme sermayesi devir hızı ile net ișletme sermayesi arasında \%21 oranında negatif yönlü bir ilișki vardır. Net ișletme sermayesinin artması devir hızını düşürmektedir. Çünkü net işletme sermayesi, satışlardaki artıştan daha yüksek oranda artmış olabilir. Net işletme sermayesi ile hasılat arasında pozitif yönde \%17 oranında bir iliş̧ki vardır. Satışlar \%1 arttıkça net işletme sermayesi devir hızı \%17 oranında artmaktadır. Net işletme sermayesi devir hızı ile nis değişkeni arasında \%2 negatif yönlü ilişki olduğu tespit edilmiştir. Analiz sonuçları birlikte değerlendirildiğinde likidite gücünün ölçüldüğü cari oran ve asit test oranı analizde anlamsız çıkmış nakit oran ise anlamlı çıkmıştır. Net işletme sermayesi devir hızı ile net işletme sermayesi, hasılat ve net işletme sermayesinin pozitif veya negatif yönlü olması arasında istatistiksel bir anlamlılık vardir.

Literatürde yapılan birçok çalıșmada çalıșma sermayesi ile kârlılık, finanslama stratejileri ve makroekonomik değiş̧kenler arasındaki ilişkinin incelendiği görülmektedir. Bu çalışmada onlardan farklı olarak net işletme sermayesi ile likidite arasındaki ilişki incelenmiştir. Literatürde net işletme sermayesinin uzun vadeli finansman kaynaklarıyla arasındaki ilişki ve net işletme sermayesi unsuru olan likidite ile hisse senetlerinin likiditesi arasındaki ilişkinin araştııılmasının literatüre katkı sağlaması beklenmektedir. 


\section{KAYNAKÇA}

Akbulut, R. (2011), "IMKB'de imalat sektöründeki işletmelerde işletme sermayesi yönetiminin kârlılık üzerindeki etkisini ölçmeye yönelik bir araștırma", İstanbul Üniversitesi İşletme Fakültesi Dergisi, 40(2), 195206.

Akel, V. ve İltaş, Y. (2016), "İşletme Sermayesinin Makroekonomik Belirleyicileri: BİST'te Sektörler Arası Bir Karşlaştırma", Eskişehir Osmangazi Üniversitesi IIBBF Dergisi, 11(3), 39-70.

Akoto, R. K., Awunyo-Vitor, D. ve Angmo, P. L. (2013), "Working capital management and profitability:Evidence from Ghanaian listed manufacturing firms", Journal of Economics and International Finance, 5(9), 373-379.

Aksoy, A. ve Yalçıner, K. (2008), İşletme Sermayesi Yönetimi, Ankara: Gazi Kitabevi.

Aksoy, E. E. (2013), "İşletme Sermayesi İhtiyacını Etkileyen İşletme İçi Faktörlerin Analizi: Prais-Winsten Regresyon Uygulaması", Gazi Üniversitesi İktisadi ve İdari Bilimler Fakültesi Dergisi, 15(3), 73-86.

Apak, S., Açıkgöz, A. F., Erbay, E. R. and Tuncer, G. (2016), "Cash vs. Net Working Capital as Strategic Tools for the Long-term Relation between Bank Credits and Liquidity: Inequalities in Turkey", Procedia - Social and Behavioral Sciences, 235, 648-655.

Appuhami, B. R. (2008), "The Impact of Firms' Capital Expenditure on Working Capital Management: An Empirical Study across Industries in Thailand", International Management Review, 4(1), 11-24.

Arçelik. (2019), Arçelik A.Ş. Yatırımcı Iliş̧kileri. http://www.arcelikas.com/yatirimci, (15.03.2019).

Aselsan. (2019), Aselsan Elektronik Sanayi ve Ticaret A.Ş. Yatırımcı İlişsleri. https://www.aselsan.com.tr/trtr/yatirimci-iliskileri/Sayfalar/Iletisim.aspx, (15.03.2019).

Atmaca, M. (2016), "Finansal Oranlar Aracilığıyla Çalışma Sermayesi Bileșenlerinin Karlılığa Etkisi:Borsa İstanbul'da İşlem Gören Kimya, Plastik ve Kauçuk Şirketlerinde Bir Araştırma" Yönetim Bilimleri Dergisi, 14(28), 633-649.

Aydoğuş, B. ve Vurur, N. S. (2017), "Çalışma Sermayesi Yönetiminin Firma Kârlılığı Üzerine Etkisi:20032012 Borsa İstanbul Uygulaması", Proceedings of 2nd International Conference on Scientific Cooperation for the Future in the Economics and Administrative Sciences, 196-203, Thessaloniki.

Aygün, M. (2012), "Firma Performansı Üzerinde Çalışma Sermayesinin Etkisi: Türk İmalat Sektörü Üzerine Bir Uygulama", Ege Akademik Bakış, 12(2), 215-223.

Aytürk, Y., ve Yanık, S. (2015), "Çalışma Sermayesi Yönetimi Türkiye'deki KOBİ'lerde Karlılığı Nasıl Etkiler?", Muhasebe ve Finansman Dergisi (68), 157-168.

Bim. (2019), BiM Birleşik Mağazalar A.Ş. Yatırımcı İlişkileri. https://www.bim.com.tr/Categories/105/yatirimci-iliskileri.aspx, (15.03.2019).

Coşkun, E., ve Kök, D. (2011), "Effect of Working Capital Policies on Profitability: A Dynamic Panel Analysis", Ege Akademik Bakış, 11, 75-85.

Çakır, H. M. ve Küçükkaplan, İ. (2012), "İşletme Sermayesi Unsurlarının Firma Değeri ve Karlılığı Üzerindeki Etkisinin İMKB'de İșlem Gören Üretim Firmalarında 2000 - 2009 Dönemi İçin Analizi", Muhasebe ve Finansman Dergisi (53), 69-86.

Çelik, İ. ve Boyacıoğlu, N. (2013), "The Impact of Fixed Assets Expenditures on Working Capital Management: An Application on Manufacturing Enterperises in Istanbul Stock Exchange", Süleyman Demirel Üniversitesi Sosyal Bilimler Enstitüsü Dergisi, 1(17), 81-99.

Çelik, R., Bilen, B. ve Bilen, Ö. (2016), "The Impacts of Changes in Macro-Economic Data on Net Working Capital: The Case of Turkey's Industrial Sector" Procedia Economics and Finance(38), 122-134.

Dash, M., ve Hanuman, R. (2009), "A Liquidity-Profitability Trade-Off Model for Working Capital Management" Available at SSRN: https://ssrn.com/abstract $=1408722$ or http://dx.doi.org/10.2139/ssrn.1408722, 1-10.

Demireli, E., Başçı, E. S. ve Karaca, S. S. (2014), "İşletme Sermayesi ve Performans Göstergeleri Arasındaki İlişkiler: Borsa İstanbul Üzerine Bir Uygulama", Ege Stratejik Araştırmalar Dergisi, 5(1), 79-98.

Doğan. (2019), Doğan Şirketler Grubu Holding A.Ş. Yatırımcı İlişkileri. http://www.doganholding.com.tr/yatirimci-iliskileri/Default.aspx, (15.03.2019). 
Doğan, M. ve Elitaş, B. L. (2014), "Çalışma Sermayesi Gereksinimlerinin Belirleyicileri: Borsa İstanbul Gıda Sektörü Üzerine Bir İnceleme", Muhasebe Bilim Dünyası Dergisi, 16(2), 1-14.

Dong, H. P. and Su, J.-t. (2010), "The Relationship between Working Capital Management and Profitability: A Vietnam Case", International Research Journal of Finance and Economics(49), 59-67.

Dursun, A. ve Ayrıçay, Y. (2012), "Çalışma Sermayesi Karlılık İlişsisinin İMKB Örneğinde 1996-2005 Dönemi Analizi", Erzurum Atatürk Üniversitesi İktisadi ve İdari Bilimler Fakültesi Dergisi, 26(3-4), 199-214.

Ebenezer, A. B. and Asiedu, M. K. (2013),"The Relationship Between Working Capital Management and Profitability of Listed Manufacturing Companies in Ghana", International Journal of Business and Social Research, 3(2), 25-34.

Enerjisa. (2019), Enerjisa Enerji A. Ş. Yatırımcı İlişkileri, https://www.enerjisainvestorrelations.com/, (15.03.2019).

Enqvist, J., Graham, M. and Nikkinen, J. (2014), "The impact of working capital management on firm profitability in different business cycles: Evidence from Finland" Research in International Business and Finance(32), 36-49.

Ereğli Demir Çelik. (2019), Ereğli Demir ve Çelik Fabrikaları T. A .Ş. Yatırımcı ilişskileri. https://www.erdemir.com.tr/yatirimci-iliskileri/, (15.03.2019).

Falope, O. I. and Ajilore, O. T. (2009), "Working Capital Management and Corporate Profitability: Evidence from Panel Data Analysis of Selected Quoted Companies in Nigeria", Research Journal of Business Management, 3(3), 73-84.

Ford. (2019), Ford Otomotiv Sanayi A. S. Yatırımcl Ilişsileri. https://www.fordotosan.com.tr/tr/yatirimcilar/yatirimci-iliskileri-anasayfasi, (15.03.2019).

Garcia-Teruel, P. J. and Martinez-Solano, P. (2009), "Effects of working capital management on SME profitability", International Journal of Managerial Finance,, 3(2), 164-177.

Gill, A., Biger, N. and Mathur, N. (2010), "The Relationship Between Working Capital Management And Profitability:Evidence From The United States", Business and Economics Journal, 1-9.

İltaş, Y. (2016), "Türkiye Cumhuriyet Merkez Bankası Sektör Bilançolarını Kullanarak İşletme Sermayesi Gereksinimi Etkileyen Değişkenler Üzerine Bir Analiz: 1996-2013", Erciyes Üniversitesi İktisadi ve İdari Bilimler Fakültesi Dergisi(48), 123-143.

Iqbal, A. and Zhuquan, W. (2015), "Working Capital Management and Profitability Evidence from Firms Listed on Karachi Stock Exchange", International Journal of Business and Management, 10(2), 231-235.

Karadağll, E. C. (2012), "The Effect of Working Capital Management on the Profitability of Turkish SMEs," British Journal of Economics, Finance and Management Sciences, 5(2), 36-44.

Karaduman, H. A., AKBAŞ, H. E., Özsozgun, A. and Durer, S. (2010), "Effectc of Working Capital Management on Profitability: The Case for Selected Companies in The Istanbul Stock Exchange (2005-2008)", International Journal of Economics and Finance Studies, 2(2), 47-54.

Kardemir. (2019), Kardemir Karabük Demir Çelik Sanayi ve Ticaret A. Ş. Yatırımcı İlişkileri. https://www.kardemir.com/sunumlar_raporlar_ve_tablolar, (15.03.2019).

Kendirli, S. ve Konak, F. (2014), "İşletme (Çalışma) Sermayesi Yönetiminin Firma Performansı Üzerindeki Etkisi: BíST Gıda, İçecek Endeksi Uygulaması", Akademik Bakış Uluslararası Hakemli Sosyal Bilimler Dergisi(41), 0-0.

Keskin, R. ve Gökalp, F. (2016), "Çalıșma Sermayesi Yönetiminin Firma Karlılı̆̆ı Üzerine Ekkisi: Panel Veri Analizi", Doğus Üniversitesi Dergisi, 17(1), 15-25.

Koç Holding (2019), Koç Holding A. Ş. Yatırımcı İlişskileri. https://www.koc.com.tr/tr-tr/yatirimci-iliskileri, (15.03.2019).

Koza Altın. (2019), Koza Altın İşletmeleri A.Ş. yatırımcı ilişskileri, http://kozaaltin.com.tr/yatirimciiliskileri/finansal-bilgiler/, (15.03.2019).

Koza Anadolu. (2019), Koza Anadolu Metal Madencilik İşletmeleri A.Ş. yatırımcı ilişsileri. http://www.kozametal.com.tr/yatirimci-iliskileri/faaliyet-raporlari/, (15.03.2019).

Kök, D., Coşkun, E. ve İspir, M. S. (2013), "Çalışma Sermayesi Politikalarında Sektörel Farklılaşma ve Ortalamaya Dönme Eğilimi", Business and Economics Research Journal, 4(4), 49-70. 
Lazaridis, I. and Tryfonidis, D. (2006), "Relationship between Working Capital Management and Profitability of Listed Companies in the Athens Stock Exchange", Journal of Financial Management and Analysis, 19(1), 1-12.

Makori, D. M. and Jagongo, A. (2013), "Working Capital Management and Firm Profitability: Empirical Evidence from Manufacturing and Construction Firms Listed on Nairobi Securities Exchange Kenya", International Journal of Accounting and Taxation, 1(1), 1-14.

Mehrotra, S. (2013), "Working Capital Trends and Liquidity Analysis of Fmcg Sector in India", IOSR Journal of Business and Management, 9(4), 45-52.

Mousavi, Z. and Jari, A. (2012), "The Relationship between Working Capital Management and Firm Performance: Evidence from Iran", International Journal of Humanities and Social Science, 2(2), 141-146.

Mueller, F. W. (1953), "Corporate Working Capital and Liquidity", The Journal of Business of the University of Chicago, 26(3), 157-172.

Öz, Y. ve Güngör, B. (2007), "Çalışma Sermayesi Yönetiminin Firma Karlılığı Üzerine Etkisi: İmalat Sektörüne Yönelik Panel Veri Analizi", Atatürk Üniversitesi Sosyal Bilimler Enstitüsü Dergisi, 10(2), 319-332.

Pegasus. (2019), Pegasus Hava Taşımacılı̆̆ı A. Ş. yatırımcı İlişkileri. http://www.pegasusyatirimciiliskileri.com/tr, (15.03.2019).

Petkim. (2019), Petkim Petrokimya Holding A.S. yatırımcı ilişsileri. http://www.petkim.com.tr/Sayfa/1/270/YATIRIMCI-ILISKILERI.aspx, (15.03.2019).

Pouraghajan, A. and Emamgholipourarchi, M. (2012), "Impact of Working Capital Management on Profitability and Market Evaluation: Evidence from Tehran Stock Exchange", International Journal of Business and Social Science, 3(10), 311-318.

Poyraz, E. (2012), "İşletme Sermayesi Finanslama Stratejilerinin Kârlılık Oranları Üzerindeki Etkisi (Akbank T.A. Ș. Uygulaması)", Dokuz Eylül Üniversitesi Íktisadi ve İdari Bilimler Fakültesi Dergisi, 27(1), 47-56.

Raheman, A. and Nasr, M. (2007), "Working capital management and profitability-case of Pakistani Firms", International Review of Business Research Papers, 3(1), 279-300.

Sabancl. (2019), Haci Ömer Sabancl Holding A.Ş. Yatırımcl Illişsileri, https://yatirimciiliskileri.sabanci.com/tr, (15.03.2019).

Sagan, J. (1955), "Toward a Theory of Working Capital Management", The Journal of Finance, 10(2), 121129.

Saglam, N., Kagitci, A. and Buyukipekci, S. (2016), "Relationship Between Working Capital Management and Profitability in Turkey Industrial Listed Companies", Journal of Modern Accounting and Auditing, 12(3), 147 155.

Soda Sanayi. (2019), Soda Sanayi A. Ş. yatırımcı Illişskileri. http://www.sisecamkimyasallar.com/tr/yatirimciiliskileri/sunumlar-ve-raporlar/yatirimci-sunumlari, (15.03.2019).

Şahin, O. (2011), "İMKB'ye Kayıtlı İmalat Şirketlerinde Çalışma Sermayesi Politikaları ve Firma Performansı İlişkileri", Eskişehir Osmangazi Üniversitesi İIBF Dergisi, 6(2), 123-141.

Şekeroğlu, G. (2013), "Çalışma Sermayesi Finanslama Stratejilerinin Firma Kârlılı̆̆ı Üzerine Etkisi: IMKB'de Kayıtlı Firmalar Üzerinde Bir Araştırma", Konya: Selçuk Üniversitesi Sosyal Bilimler Enstitüsü, İșletme Anabilim Dalı Yüksek Lisans Tezi.

Şişe Cam (2019), Türkiye Şişe ve Cam Fabrikaları A.Ş. Yatırımcı İlişkileri. http://www.sisecam.com.tr/tr/yatirimci-iliskileri/sunumlar-ve-raporlar/yillik-faaliyet-raporlari, (15.03.2019).

Tav. (2019, Tav Havalimanları Holding A.Ş. Yatırımcı Ilişsileri. http://www.tavyatirimciiliskileri.com/trTR/Pages/IndexPage.aspx, (15.03.2019).

Tekfen. (2019), Tekfen Holding A.Ş. http://www.tekfen.com.tr/yatirimci_iliskileri.asp?n=1\&p=17, (15.03.2019).

Thy. (2019), Türk Hava Yolları A.Ş. Yatırımcı İlişkileri, http://investor.turkishairlines.com/tr, (15.03.2019).

Tofaş. (2019), Tofaş Türk Otomobil Fabrikası A.Ş. Yatırımcı Ilişskileri. https://www.tofas.com.tr/Yatirimcilliskileri/FinansalSonuclar/Pages/default.aspx, (15.03.2019). 


Turkcell. (2019), Turkcell Iletişim Hizmetleri A.Ş. Yatırımcı Ilişkileri.

https://www.turkcell.com.tr/tr/hakkimizda/yatirimci-iliskileri, (15.03.2019).

Tüpraş. (2019), Türkiye Petrol Rafineleri A.Ș. Yatırımcı Illişkileri, https://www.tupras.com.tr/genel-bakis, (15.03.2019).

Türk Telekom. (2019), Türk Telekomünikasyon A.Ş. Yatırımcı İlişkileri. http://www.ttyatirimciiliskileri.com.tr/tr-tr/sayfalar/default.aspx, (15.03.2019).

Ulusoy, T., Esmer ,Y. ve Dayı, F. (2019), "Spor İșletmelerinde Nakit Yönetimi: BİST'de Bir Uygulama", Manas Sosyal Araştırmalar Dergisi, 8(2), 1889-1905.

Uremadu, S. O., Egbide, B.-C. and Enyi, P. E. (2012), "Working Capital Management, Liquidity and Corporate Profitability among quoted Firms in Nigeria Evidence from the Productive Sector", International Journal of Academic Research in Accounting, Finance and Management Sciences, 2(1), 80-97.

Yamaltdinova, A. (2018), "Enerji Sektöründe Faaliyet Gösteren Firmaların Performansına Çalışma Sermayesinin Etkisi", SESSION 3C: Sektörel analiz, 325-331. 